\title{
EFFECT OF CHEMICAL AND BIOCHEICAL TREATMENTS FOR SUGAR BEET VIEN SILAGE ON : II - REDUCTION OF OXALIC ACID CONTENTES TO IMPROVEMENT SUGR BEET SILAGE QUALITY AND NITROGEN UTILIZATION .
}

Saleh, M. R. M. ; G. I. Elemam and M. M. Refaay

Animal Production Res. Institute, Agric. Research Center ,Dokki, Egypt .

\begin{abstract}
This work was designed to process sugar beet by-products treated and untreated on form of silage and trying to overcome harmful oxalic acid as anti nutritional factor to improving of sugar beet top by ensiling either untreated or treated sugar beet top by supplemented with calcium carbonate as chemical treated (CSBS) or calcium carbonate+ pro biotic as biochemical treated (Biochemical) .Four digestion trials were carried out using three rams in each. The animals were nearly equal in body weight $62.4 \pm 0.7 \mathrm{~kg}$, and fed the experimental diets according to NRC(1990). group 1 fed $50 \%$ pellets $+50 \%$ clover hay $(\mathrm{CH})$ as a control , group 2,3 and 4 were fed $50 \%$ pellets $+50 \%$ one of different types of silages. The effect of replacing clover hay by different types of treated or untreated sugar beet tops silage on DM intake, Digestion coefficient, nutritive values, nitrogen balance were studded. Also hematological parameters of white blood cells (WBC's) packed cells volume (PCV \%) were also determined.

The results indicated that both of chemical and biochemical treated silage were excellent have a firm texture, good smell, free from sign of mold, dust smells caramelized and tobacco or vinegar . All silages had a normal of $\mathrm{pH}$ (3.98-4.11) with the superiority of those biochemical treated silage 4.58. The over all mean of TVFAs ranged between $(5.44-7.29) \mathrm{ml} \mathrm{mol} / 100 \mathrm{ml}$, being higher for treated silages. Biochemical treated silage recorded the least concentration of NH3-N (16.67gm/100gm) .The fast rate of $\mathrm{pH}$ decline with untreated silage, whereas the Biochemical treated silage was remained unspoiled and markedly improved aerobic stability of silage. Data showed that nitrogen balance are the best within B-CSBS than all tested treatments. The ensiling of sugar beet tops with additives depressed the presence of anti-nutrition factors. also results clearly that rams fed on treated ensiled were increased significantly $(p<0.05)$ the digestibility of OM ,CP,CF,NDF and ADL and improved significantly $(p<0.05)$ TDN and DCP values. Ensilage of sugar beet tops with Biochemical had high advantages, improved the aerobic stability of silage and participate in feeding animals and minimize such problems of disposal pollution .

Keywords : Chemical, Biological treatments, nitrogen balance, Rahmany rams, packed cells volume, Digestion coefficient.
\end{abstract}

\section{INTRODUCTION}

In Egypt animal feed resources are limited which do not allow increasing livestock population to a level satisfies human demands. moreover feed shortage is also un evenly divided between summer and winter .where in winter season; berseem is the major forage crop covering nearly 46 and $125 \%$ of yearly animal requirement of energy and protein, respectively Abou-Selim and Bendary,2005). While in summer season, the available feeds are mainly concentrate and straw which cover about $40 \%$ and $22 \%$ the local animal requirements of energy and protein respectively confirm that 
using crop wastes in animal diets could participate in reduce the shortage of animal feeds and subsequent increase milk and meat production .Chemical and biological treatments such as fungi ( Abdelhamid et al .,2006 \& 2007) as Trichoderma viride (Abdelhamid et al.,2009a,b\&c) and penicillium (fniculusms ( El- Ashry et al., 2003 ) were used to improve the nutritive value of nutrients especially crude fiber, in term of elevation of rumen microorganisms( Dawson,1992).and digestibility). (El-Serafy,1991But there are a problem of natural harmful oxalic acids contain because when you eat foods containing oxalic acid, this substance can interfere with the absorption of minerals in those foods, such as calcium, magnesium and potassium. Oxalic acid also can combine with minerals in the body, creating oxalate crystals that may cause problems for people prone to kidney stones or gout. The U.S. Department of Agriculture lists oxalic acid content in foods by parts per million (ppm), as compiled by Abdelhamid and Saleh (1998). The LD50 for pure oxalic acid is predicted to be about $378 \mathrm{mg} / \mathrm{kg}$ body weight, or about $22 \mathrm{~g}$ for a $60 \mathrm{~kg}$ human. The affinity of divalent metal ions is sometimes reflected in their tendency to form insoluble precipitates. Oxalic acid also combines with metals such as calcium, iron, sodium, magnesium, and potassium in the body to form crystals of the corresponding oxalates, which irritate the gut and kidneys. Because it binds vital nutrients such as calcium, long-term consumption of feeds high in oxalic acid can lead to nutrient deficiencies. Since many years noticed that some fungal species for production large amount of oxalic acid on moist straw, that mean the oxalic acid is one of mycotoxin , its produced by A .flavus and A .niger (Gredek ,1974 \& 1983 ) .

The main objective of this study was to determine the influence of incorruption of different kind of silage made from sugar beet tops wastes on harmful oxalic acid and nutritive value by rams .

\section{MATERALS AND METHODS}

This study was carried out in El-Serw Animal Production Research Station,(Damietta governorate),Animal Production Research Institute , Agriculture Research Center Dokki, Giza, Egypt during June, 2008 .

\section{Experimental animal rations and Management}

To study the effect of feeding rams on the tested three different types of silage, four digestion trials were conducted on mature rahmany rams selected from El-Serw herd ( 3 animal each), with an average $62.4 \mathrm{~kg}$ weight, All rams were healthy and free of diseases. The rams (12 animals were divided randomly into four similar groups (according to body weight).Rams were housed in groups and kept under shade.

Experimental rations and feeding system

The experimental rations were therefore as :

Ration $1-50 \%$ CFM (pellets) $+50 \%$ clover hay(control).

Ration $2-50 \%$ CFM ( pellets) $+50 \%$ untreated sugar beet top .

Ration $3-50 \%$ CFM (pellets) $+50 \%$ chemical treated sugar beet top .

Ration $4-50 \%$ CFM ( pellets) $+50 \%$ biochemical treated sugar beet top .

Chemical analysis of ingredients and diets are presented in Table (1) feed

allowance were calculated according to NRC1990. Feed was offered two 
times/day at 8 am and $3 \mathrm{pm}$.

\section{Concentrate feed mixture}

The formula of concentrate feed mixture pellets following : corticated cotton seed $17.0 \%$, yellow corn $44 \%$, wheat bran $25 \%$, soy been meal ( $44 \%$ CP), $7 \%$ common salt $1.5 \%$ and $5 \%$ molasses .

\section{Silage preparation}

Fresh sugar beet tops which collected from El-Serw Damietta's government after harvested were chopped $(10-15 \mathrm{~cm})$ by a hand machine and sun dried for a period of 3 days to reach a moisture content of about $65-70$ $\%$, the silage was prepared by filling successive layers of the shopped materials and heavy trodden before adding the next layers. However, each layer was consisted of the sugar beet tops and chopped rice straw $(4: 1)$ molasses was added at the rate of $5 \%$ all silages were put in plastic bags for 8 weeks, then the bags were opened the color and odor were examined directly representative samples were taken from each kind of silage materials before and after ensiling for chemical analysis .

\section{Untreated silage ( USBS )}

Whole wilted and chopped green sugar beet tops it mixed with $5 \%$ molasses was added during the silage making, then it. was ensiled in plastic bags for 2 month before feeding. After ensilage period, the color and odor were examined and samples were taken for chemical analysis determine silage quality.

\section{Chemical treated sugar beet tops ( CSBS )}

Untreated silage Sugar beet tops were mixed with 3\% calcium carbonate Biochemical treated sugar beet silage ( B-CSBS )

Chemical treated sugar beet tops was mixed with $1 \%$ pro biotic as biological treating.

\section{Silage quality measurements}

Samples from all types of silages ( USBS, CSBS AND B-CSBS ) were taken at the opening time and during the experimental period .The $\mathrm{pH}$ was measured using a digital $\mathrm{pH}$ mater, while ammonia concentration determined according to Conway ( 1962 ). The left of the filtrate was kept frozen at $-20^{\circ} \mathrm{C}$ for TVFA determination according to Warner(1964) Lactic acid determined according to Waldo and Schultz ( 1996 ) .

\section{Digestibility trials}

Four digestibility trials were conducted using three adult rams for each to determine the digestion coefficients blood picture and analysis for the different treatments. Each trial lasted for 22 day the first 15 -day was considered as a preliminary period followed by 7 -days as a collection period .

\section{Blood parameters}

Blood profile was completed by estimations of some biochemical parameters in the blood serum for animals fed tested rations. Throughout the feeding period 8 am and $3 \mathrm{pm}$, blood samples were collected from each animal at early morning before feeding from the jugular vein into vacationer tubes. Hematological parameters including white blood cells (WBC's) packed cells volume (PCV\%) and hematology concentration. Whereas other samples were allowed to clot and centrifuged at $3500 \mathrm{rpm}$ for 20 minutes to separated blood serum .serum was carefully decanted into labeled tubes using 
serological pipettes and stored at $20^{\circ} \mathrm{C}$ until analysis. Total protein and albumin concentration were determined using commercially kits according to Douman et al.,(1971) .

Samples collection

At the last week of the experiment, faces and urine samples were collected daily for seven successive days from three animals for each group for nutritive values determination. Representatively samples of feed and fresh feces were dried and ground then mixed and kept for chemical analysis to estimator the nutrients digestibility. Urine was collected daily after mixed with $20 \mathrm{ml}$ conc . Sulfuric acid to keep ammonia messed.

\section{Analytical methods}

Chemical analysis of feed ingredients and feces was carried out according to A.O.A.C. (2000) . oxalic acid was determined according to Fengwu et al., (1999 ).Mycotoxins was determined according to modified model of (Abdelhamid and Saleh 1996) . Plasma biochemical analysis was done using Biomerieux reagent kits.Total volatile fatty acid(TVFA)of silage aqueous extract was measured by the methods of Patel and Mudgal (1974).

\section{Statistical analysis}

All numerical data obtained were statistical analyzed by SAS (1996) procedures for personal computer. When F-test was positive, least significant differences Duncan (1955) within program SPSS was done to determine the degree of significance between means.

\section{RESULTS AND DISCUSSION}

\section{Chemical analysis}

Results in Table (1) showed the chemical analysis of the experimental feedstuffs and rice straw. Data showed that biological treated silage (BCSBS) was higher in DM, CP, EE and NFE compared with other silages , whereas it was decreased in CF and ash.The values were 68.04 DM , 87.47OM , 14.89 CP , 7.61CF, 3.36 EE , 12.53 Ash and 57.62 NFE. Data indicated that USBS contain the lowest vales of DM , CP and EE. It was notice that the addition of effective microorganisms (probiotic)+ calcium carbonate during ensilage to CSBS and B-CSBS improved CP,CF and NFE, while decrease oxalic acid contents than those of USBS these results are in agreement with Mohsen et al .,(2006). Who found that silage making decrease CF and cell wall components, but increase EE and ash contents . Also Biomin (2008).mentioned that inoculants lead to higher production of lactic acid and therefore lower $\mathrm{pH}$ value, decrease butyric acid fermentation or inhibition of the clostridia fermentation and a higher recovery of energy in the ensilage matter. Bendary et al ., ( 1992 a \& b) who indicated that sugar beet tops (SBT)as fresh, dried or silage made by different methods had high feeding value and more palatable compared to other roughage by-products. However, there are some problems to use fresh sugar beet tops because it has contain of natural harmful oxalic acid which causing kidney, liver and hart disease(Saleh et al .,2008) .on the other side all results obtained indicated that sugar beet tops(SBT)as fresh, dried or silage made by different 
methods had high feeding value and more palatable compared to other field west(Abdelhamid and El-Emam ., 2001) . Decreasing of crude fiber of BCSBS may be due to the effect of the librations of cellulose formats bonds with lignin( delignification which increased solubility( Abd El- Hamid and saleh.,1989).This result agreed with Chauhan and Kakkar(1981).and Zedan (1998).Similar results have been reported with urea treatment of rice straw , corn Stover sugarcane tops at ensilaging(Abd El-Aziz,1993 Talha 1990;Tabanah 1994 ,Chauhan ,1994 and Abd El-A ziz,et al.,1997) subsequent there are Similar results were reported by Mohamed (1998\& 2003).who found that treatment corn Stover silage with1\%urea and 3\% molasses at ensiling decreased its NDF, ADF and ADL contents .

Table (1): Analysis of ingredients, different types of silage and experimental diets .

\begin{tabular}{|l|c|c|c|c|c|c|c|}
\hline \multirow{2}{*}{ items } & \multirow{2}{*}{ pallets } & \multirow{2}{*}{ BH } & \multirow{2}{*}{ RS } & \multicolumn{5}{|c|}{$\begin{array}{c}\text { Experimental rations } \\
\text { on (DM bases) }\end{array}$} \\
\cline { 5 - 9 } & & & COTROL & UTSBS & CSBS & B-CSBS \\
\hline Chemical composition (\%) \\
\hline DM & 89.82 & 88.11 & 89.56 & 88.68 & 62.54 & 65.41 & 68.04 \\
\hline OM & 90.17 & 89.23 & 81.15 & 89.92 & 84.75 & 81.56 & 87.47 \\
\hline CP & 13.92 & 14.16 & 3.42 & 13.97 & 12.58 & 12.66 & 14.89 \\
\hline CF & 11.78 & 24.79 & 33.74 & 18.29 & 14.30 & 14.00 & 7.61 \\
\hline EE & 3.29 & 3.05 & 1.63 & 3.24 & 3.36 & 3.09 & 3.36 \\
\hline Ash & 9.83 & 10.77 & 18.85 & 10.08 & 15.26 & 18.45 & 12.53 \\
\hline NFE & 61.18 & 47.23 & 44.13 & 56.09 & 54.51 & 50.82 & 57.62 \\
\hline
\end{tabular}

Oxalic acid

Oxalic acid is very harmless for human and animals because it causing kidney and liver damage. Abdehamid and Saleh (1998). People with recurrent kidney stones have a tendency to absorb higher levels of dietary oxalates compared to those not prone to kidney stones. Data of oxalic acid, Table(2). Clearly that USBS group was higher significant difference $(p<0.05)$ than CSBS and B-CSBS groups, whereas B-CSBS recorded lower value of oxalic acid and this may be due to bicarbonate and pro biotic supplemented to silage among silage making. This results agree with that obtained by Abelhamid and El-emam (2001). A low-oxalate diet is eating foods containing less than $50 \mathrm{mgs}$ of oxalic acid per day. Saleh (1999). Oxalic acid also combines with metals such as calcium, iron, sodium , magnesium, and potassium in the body to form crystals of the corresponding oxalates, which irritate the gut and kidneys. Because it binds vital nutrients such as calcium, long - term consumption of feeds high in oxalic acid can lead to nutrient deficiencies. 
Saleh, M. R. M. et al.

Table (2): Oxalic acid contain in diets, feces and $\mathrm{mg} / 100$ (gm/or $\mathrm{ml}$ ).

\begin{tabular}{|l|c|c|c|}
\hline \multirow{2}{*}{\multicolumn{1}{|c|}{ Items }} & \multicolumn{3}{|c|}{ Oxalic acid $\mathbf{\mu g} / \mathbf{1 0 0} \mathbf{~ g m ~ o r ~} \mathbf{~ m l}$} \\
\cline { 2 - 4 } & USBS & CSBS & B-CSBS \\
\hline Diets & $9.82 \mathrm{a}$ & $3.95 \mathrm{~b}$ & $3.87 \mathrm{~b}$ \\
\hline Feces & $2.67 \mathrm{a}$ & $0.86 \mathrm{~b}$ & $0.74 \mathrm{~b}$ \\
\hline Urine & $4.21 \mathrm{a}$ & $1.73 \mathrm{~b}$ & $1.51 \mathrm{~b}$ \\
\hline rumen liquor & $7.21 \mathrm{a}$ & $1.58 \mathrm{~b}$ & $1.19 \mathrm{~b}$ \\
\hline Blood & $2.48 \mathrm{a}$ & $0.70 \mathrm{~b}$ & $0.28 \mathrm{~b}$ \\
\hline Total excretion & $6.88 \mathrm{a}$ & $2.59 \mathrm{~b}$ & $1.05 \mathrm{~b}$ \\
\hline
\end{tabular}

Means having different superscripts within the same row are significantly different at $\mathrm{P}<0.05$.

\section{Mycotoxins}

Data in Table (3). Clearly that Aflatoxin B1 and ochratoxin A were adjust absence in both chemical and bio- chemical treated silage, whereas the values of aflatoxin B1 and ochratoxin A with Untreated sugar beet silage were 13.72 and $76.8 \mathrm{ppb}$ for aflatoxin B1 and ochratoxin A respectively .this may be bach to calcium bicharbonat and probiotic supplemented to silage .subsequent the aflatoxin B1 and ochratoxinA impair liver and kidney function , delay blood clotting,increase susceptible to bruising,and interfere with cellular humoral immune system(Diekman and Green ,1992) as well as suppression of cellular immunity( Qureshi et al .,1998).So, inhibition of DNA , RNA and protein synthetic via a variety of different mechanisms appears to be directly or indirectly responsible for the immunosuppressive action of many mycotoxins(Correr 1991).Studies have linked human exposure to Aflatoxins to increase prevalence of infection(IARC,2002).Its chronic symptoms include liver and kidney damage , reduced growth, anemia, bruising and immune suppression( Heman and Ttigo - Stockli 2008 ).The biochemical effects of aflatoxins included carbohydrate metabolism, endocrine system,and skeletal system(Verma ,2007) as well as DNA damage (El- Barbary , 2008). Mycotoxins are found frequently in different feedstuffs (Sawamy 2009). And treat not only plant crops, but also animal and human health . El-Shenawy et al .(2005).

Table (3): Mycotoxins Aflatoxin $B 1\left(A_{B 1}\right)$ and Ochratoxin $A\left(O N_{A}\right)$ ppb/kg .

\begin{tabular}{|c|c|c|c|c|}
\hline \multirow{2}{*}{ Items } & \multirow{2}{*}{ control } & \multicolumn{3}{|c|}{ Oxalic acid $\mathbf{~ n g ~ / ~ 1 0 0 ~ g m ~ o r ~} \mathbf{~ m l}$} \\
\cline { 3 - 5 } & & USBS & CSBS & B-CSBS \\
\hline Aflatoxin $\mathrm{B} 1 \mathrm{ppb} / \mathrm{kg}$ & $81.7 \mathrm{a}$ & $13.72 \mathrm{~b}$ & - & - \\
\hline Ochratoxin $\mathrm{A} \mathrm{ppb} / \mathrm{kg}$ & $126.3 \mathrm{a}$ & $76.8 \mathrm{~b}$ & - & - \\
\hline
\end{tabular}

Means having different superscripts within the same row are significantly different at $\mathrm{P}<0.05$.

\section{Hematological and Biochemical parameters}

Data of some hematological parameters of the blood collected from animals feed the tested rations are presented in Table (4).There were significant differences $(p<0.05)$ decrease in erythrocyte and leucocytes for USBS compared with B-CSBS, CSBS and control groups. On the other hand the neutrophile, lymphocyte $\%$ and eiosinophile were significantly increased 
$(p<0.05)$ with USBS group, whereas the monocyte significantly decrease to same group. This increases of lymphocyte and neutrophile for USBS group may be due to the increases of oxalic acid level and decreases of protein than the B-CSBS , CSBS and control groups. Addition to that oxalic acid have an enhancement effect to the humoral immune response and increase white blood cells (Pollman et al., 1980).

Table (4): Blood picture of rams fed different type of sugar beet tops silage

\begin{tabular}{|c|c|c|c|c|}
\hline \multirow{2}{*}{ Items } & \multirow[t]{2}{*}{ Control } & \multicolumn{3}{|c|}{ Sugar beet tops } \\
\hline & & USBS & CSBS & B-CSBS \\
\hline \multicolumn{5}{|l|}{ Hematological parameters . } \\
\hline Hematocrit values (\%) & 18.5 & $22.34 a$ & $16.97 \mathrm{~b}$ & $15.76 \mathrm{c}$ \\
\hline White blood cells(x103/ mm3 ) & $6.09 b$ & $7.41 \mathrm{a}$ & $6.43 b$ & $6.19 b$ \\
\hline Lymphocyte (\%) & $56.11 \mathrm{~b}$ & $62.97 a$ & $57.98 \mathrm{~b}$ & $57.3 b$ \\
\hline Neutrophile (\%) & $43.43 b$ & $58.76 a$ & $42.53 b$ & $41.8 b$ \\
\hline Eiosinophile (\%) & $5.34 b$ & $7.14 \mathrm{a}$ & $4.87 \mathrm{~b}$ & $4.7 \mathrm{~b}$ \\
\hline Monocyte (\%) & $17.66 b$ & $15.12 \mathrm{c}$ & $22.16 a$ & $21.9 a$ \\
\hline \multicolumn{5}{|l|}{ Biochemical parameters . } \\
\hline AST $(\mathrm{u} / \mathrm{ml})$ & $64.0 \mathrm{a}$ & $71.23 a$ & $23 b$ & $16.00 b$ \\
\hline $\mathrm{ALT}(\mathrm{u} / \mathrm{ml})$ & $54.0 a$ & $49.27 a$ & $14 b$ & $11.83 b$ \\
\hline Creatinin (mg /100ml) & $0.94 a$ & $1.18 \mathrm{a}$ & $0.27 b$ & $0.33 b$ \\
\hline Bilirubin ( mg /100ml) & $0.52 a$ & $0.68 a$ & $0.29 b$ & $0.23 b$ \\
\hline Alk-P-ase ( lu / I ) & $76.4 \mathrm{a}$ & $96.57 a$ & $18.23 \mathrm{~b}$ & $11.55 b$ \\
\hline
\end{tabular}

Means having different superscripts within the same row are significantly different atP < 0.05 .

\section{Nitrogen utilization}

Results concerning nitrogen intake, excretion and balance are presented in Table(5) .Nitrogen balance $(\mathrm{g} / \mathrm{h} / \mathrm{d})$ was positive in all tested groups fed the experimental rations indicated that the animal were in normal $\mathrm{N}$ metabolism status, a condition necessary for accurate evolution of the tested rations. The highest values of NB was found in B-CSBS and CSBS this may be attributed to presence of treated silage in rations ( EI - Kady et al $., 1999)$.

This result indicated that effective microorganisms before ensilage process particularly with biochemical treatment was improved nitrogen digestion as a percentage of intake $(62.00,55.46,50.93$ and $54.59 \%$ for BCSBS ,CSBS, USBS and control, respectively ). This result is agreement with the finding of (Saleh et al., 2007) and (Bendary et al ., 1992 a) .

Table (5): Nitrogen utilization of rams fed on different sugar beet top silage.

\begin{tabular}{|l|c|c|c|c|}
\hline \multicolumn{1}{|c|}{ ITEMS } & Control & USBS & CSBS & B-CSBS \\
\hline Nitrogen intake $\mathrm{mg} / \mathrm{kg} \mathrm{BW}$ & $75.48 \mathrm{~b}$ & $68.05 \mathrm{a}$ & $71.64 \mathrm{a}$ & $74.49 \mathrm{a}$ \\
\hline Feces nitrogen $\mathrm{mg} / \mathrm{kg} \mathrm{BW}$ & $17.89 \mathrm{~b}$ & $19.06 \mathrm{a}$ & $15.26 \mathrm{c}$ & $14.89 \mathrm{c}$ \\
\hline Urine nitrogen $\mathrm{mg} / \mathrm{kg} \mathrm{BW}$ & $16.38 \mathrm{a}$ & $14.33 \mathrm{~b}$ & $16.65 \mathrm{~b}$ & $13.42 \mathrm{~b}$ \\
\hline Total nitrogen excretion mg/kg BW & $34.27 \mathrm{a}$ & $33.39 \mathrm{a}$ & $31.91 \mathrm{a}$ & $28.31 \mathrm{a}$ \\
\hline Digestion nitrogen $\mathrm{mg} / \mathrm{kg} \mathrm{BW}$ & $41.21 \mathrm{c}$ & $34.66 \mathrm{~b}$ & $39.73 \mathrm{~b}$ & $46.18 \mathrm{a}$ \\
\hline Digestion nitrogen of nitrogen intake & $54.59 \mathrm{~b}$ & $50.93 \mathrm{~b}$ & $55.46 \mathrm{~b}$ & $62.00 \mathrm{a}$ \\
\hline
\end{tabular}

Means having different superscripts within the same row are significantly different at $\mathbf{P}<$ 0.05 . 


\section{Silage quality silage $\mathrm{pH}$}

The $\mathrm{pH}$ values in Table (6) were 4.4.39, 4.11 and 3.98 for CSBS , USBS and B-CSBS respectively. The data showed that the $\mathrm{pH}$ value were decreased for B-CSWS . This agreement with the result obtained by Austin (1997) who found a high significant correlation between Urea supplemented to silages and $\mathrm{pH}$ value. The $\mathrm{Ph}$ value is an important criteria of the B-CSBS which reflected the change occurred during ensilage. at the same time, it is considered the simple method to predict the silage quality The fast rate of $\mathrm{pH}$ decline with silages imply quick establishment of anaerobic condition in the container, which in turn promote a growth of lactic acid and minimize time of ensilage by about tow weeks. These results are in agreement with those obtained by Yacout (2001) found that $\mathrm{pH}$ value of all silage reached a plateau between 3.85 and 4.20 with a trends lower $\mathrm{pH}$ value with treated silages which indicated good silage fermentation.

\section{Lactic acid concentration}

Lactic acid concentrations were $4.28,4.62$ and 5.23 for USBS,CSBS and B-CSBS respectively Table (6) . The USBS was lower value of lactic acid concentration compared to other B-CSBS and CSBS silage. The results was indicated that addition of molasses to B-CSBS and CSBS through ensilage Process inhibits lactic acid formation even mach carbohydrates are available as molasses. These results are in agreement with those of Chauhan(1994). who reported that the chemical and biochemical treated silage was higher in lactic acid concentration than untreated silage. Good quality silage characteristics was related a high level of lactic acid (Barnet,1954). Mohamed (1998) and Tabanah ( 1994 ) indicated that the $\mathrm{pH}$ values had an inverse trend to lactic acid production .The soluble carbohydrates are major source for lactic acid production, which improved the silage quality .

Total volatile fatty acid concentration ( TVFA) .

The contents of TVFA's Table (6) are used for judging silage quality .Results indicated that TVFA's concentrations of silage ranged between $5.44,6.76$ and $7.29 \mathrm{ml} \mathrm{mol} / 100 \mathrm{ml}$ by week 8 for USBS, CSBS and BCSBS respectively .The total TVFA's values tended to be higher with inculcated silage .The higher quality is characterized by high TVFA's concentration ( Etman et al 1994) .

\section{NH3 - N concentration}

Results in Table (6) .Showed that ensilage NH3-N concentration of the three types of silages ranged between $18.54,22.41$ and $16.76 \mathrm{mg} / 100 \mathrm{gm}$ with a tendency to be lower with untreated silage than treated silage. The protein breakdown is almost inhibited with decreasing $\mathrm{pH}$ value, this might be due to that lactic acid organisms help to reduce the breaking of protein to ammonia (Vertanin, 1984). This results are in agreement with the feeding of Hieu (1999) .

\section{Physical properties}

The most important physical properties of silage quality are the silage smell and color the silage was excellent with a nice smell and a bright greenish-yellow color, which turned brown when exposed to air . In addition some juice were collected at the bottom of the sugar beet tops silages( SBS ) 
which contained molasses. The color tended to be brown in the sugar beet tops silage ,Hughes and Peralta( 1981) .in sugar with $\mathrm{N}$ bases via the Millard action. Hughes and Peralta (1981) observed that the SBT silage become a dark brown color with urea treatment.

Table(6): Fermentation characteristics of different type of silage (on dry matter basis ) .

\begin{tabular}{|l|c|c|c|}
\hline \multicolumn{1}{|c|}{ Item } & UTS & CSWS & BCSWS \\
\hline The $\mathrm{pH}$ value & 4.39 & 4.11 & 3.98 \\
\hline Lactic acid (mg/100g) & 4.28 & 4.62 & 5.23 \\
\hline Total volatile fatty acid (TVFA's) $\mathrm{ml} \mathrm{mol} \mathrm{/} \mathrm{100} \mathrm{ml}$ & 5.44 & 6.76 & 7.29 \\
\hline Ammonia-N (mg/100gm) & 18.54 & 22.41 & 16.67 \\
\hline Total count of microorganisms, cfu/g & $5.9 \times 105$ & $6.8 \times 107$ & $7.5 \times 108$ \\
\hline
\end{tabular}

\section{Digestion trials}

\section{Feed intake}

daily dry matter intake by rams fed either control diet ( CFM ) or treated silage diets ( USBS, CSBS and B-CSBS ) in Table (7). The results were indicated that the daily DMI of rams fed UBS was higher $(p<0.05)$ than those fed CSBS , BCSBS and control .The values were 2316, 2952, 2747, $2460 \mathrm{~g} / \mathrm{h} / \mathrm{d}$ for USBS, CSBS and B-CSBS, respectively .

\section{Nutrient digestibility and feeding values}

Data in Table (8) clearly indicated that B-CSBS was significantly higher $(p<0.05)$ in digestibility's of OM , CP,CF, EE and NFE compared with CSBS, USBS and control diet. At the same time the untreated sugar beet tops (USBS) was significantly higher $(p<0.05)$ for NDF, ADF ADL, cellulose and hemicelluloses than other all treatments. This result may be due to the microorganisms and urea supplemented during ensilage and decreasing the level of oxalic acid .

Table (7): Daily feed intake by rams fed on the different silage of Sugar beet tops.

\begin{tabular}{|c|c|c|c|c|}
\hline ITEMS & diet & DM (g/h/d ) & DM $\left(\mathrm{g} / \mathrm{kg}^{\mathrm{h}}\right)$ & DM (\%of Bw) \\
\hline \multirow{3}{*}{ Control } & CFM & 1260 & 211.48 & 1.23 \\
\hline & $\mathrm{BH}$ & 1056 & 105.25 & 0.61 \\
\hline & TOTAL & $2316 c \pm 49$ & $338 \pm 92$ & $1.84 \pm 40.3$ \\
\hline \multirow{3}{*}{ USBS } & CFM & 1278 & 214 & 1.16 \\
\hline & USBTS & 1674 & 262 & 1.41 \\
\hline & TOTAL & $2952 a \pm 28$ & $476 \pm 5.7$ & $2.57 \pm 0.04$ \\
\hline \multirow{3}{*}{ CSBS } & CFM & 1080 & 189 & 0.88 \\
\hline & CSBTS & 1667 & 261 & 1.21 \\
\hline & TOTAL & $2747 a \pm 39$ & $441 \pm 12$ & $2.05 \pm 0.03$ \\
\hline \multirow{3}{*}{ B-CSBS } & CFM & 1215 & 206 & 0.84 \\
\hline & BSBTS & 1245 & 235 & 0.95 \\
\hline & TOTAL & $2460 b \pm 18$ & $441 \pm 10$ & $1.79 \pm 40.01$ \\
\hline
\end{tabular}

Means having different superscripts within the same column are significantly different at $\mathbf{P}<0.05$. 
Table (8): Digestion coefficients and feeding values ( $\%$ on dry matter bases) of different silages fed to Rahmany rams.

\begin{tabular}{|c|c|c|c|c|}
\hline ITEMS & Control & USBS & CSBS & B-CSBS \\
\hline \multicolumn{5}{|l|}{ s digestibility \% } \\
\hline DM,$\%$ & $64.78 \pm 1.91 \mathrm{a}$ & $62.43 \pm 2.47 b$ & $65.34 \pm 2.12 \mathrm{a}$ & $67.23 \pm 2.19 a$ \\
\hline OM , \% & $62.40 \pm 1.18 b$ & $60.94 \pm 1.08 c$ & $64.84 \pm 0.6 b$ & $68.37 \pm 0.8 a$ \\
\hline $\mathrm{CP}, \%$ & $65.97 \pm 2.37 b$ & $61.37 \pm 1.44 \mathrm{c}$ & $65.44 \pm 0.75 b$ & $71.11 \pm 0.69 a$ \\
\hline $\mathrm{CF}, \%$ & $55.41 \pm 1.38 b$ & $49.34 \pm 0.67 b$ & $61.71 \pm 0.79 a$ & $66.97 \pm 0.94 a$ \\
\hline EE , \% & $67.15 \pm 2.21 \mathrm{a}$ & $63.85 \pm 1.37 b$ & $66.34 \pm 0.58 a$ & $69.38 \pm 2.32 a$ \\
\hline NFE , \% & $68.25 \pm 1.63 a$ & $61.17 \pm 1.97 \mathrm{~b}$ & $63.35 \pm 1.32 b$ & $67.57 \pm 2.15 a$ \\
\hline
\end{tabular}

Means having different superscripts within the same row are significantly different at $P<0$ .05 .

\section{CONCLUSION}

From the foregoing results it could be concluded that effective microorganisms and calcium sources as an additives for making silage of sugar beet tops was effective and closely from the view point of economy even concerning feed conversion which was statistically similar to the control So it to recommended using sugar beet tops silage with effective microorganisms and calcium sources + urea in feed ruminants without any harm effects on feed utilization and animal health, but to overcome, to some extent, the gap in animal feed stuffs by introducing sugar beet tops silage as a feed resource in the economical animal production .

\section{REFERENCES}

Abdelhamid , A.M.and Saleh M.R.M.(1996) .Are aflatoxin and ochratoxin endemic mycotoxins in Egypt ? Proc.Food born Contamination and Egyptian Health Conference Univ. , 26-27 Nov., pp 51-59.

Abdelhamid , A.M.and Saleh M.R.M. ( 1999 ) . Clinlcal and pathological effect of oxalic acid on rabbits.Toxilogical Conference. Alexand. Univ. , 24-26 October., pp289-297 .

Abdehamid, A.M. and El-emam, G.I.I. (2001). Silage making in Egypt .Ph.D.Sc.Thesis, Fac. of Agric. Sci. Mansoura Univ., 26:158-169 .

Abdelhamid,A.M.;Fayed . A.M., Ghanem ,A.Z.and Helal , H.G.(2006) .Studies on biological treatment of salt plants.1-Feed evaluation by small ruminants . J. Agreic. Sci.Mansoura Univ., 31:627-640 .

Abdelhamid , A.M.; Fayed . A.M., Ghanem ,A.Z.and Helal , H.G.( 2007) Studies on biological treatment of salt plants.II -Fattening trial . J. Agric. Sci.Mansoura Univ., 32: 151- 165 ( Oven Technical Articles , engpmix. Com ., 2007, 12p. )

Abdelhamid , A.M.;Bassuny , S.M.; Abd El- Aziz ,A.A. and Ibrahim , M.Y.S.A. (2009a). Evaluation of biological treatments for agriculture by-products in ruminants feeding 1- Laboratorial study . J.Agric.Sci. Mansoura Univ., 34: 6227- 6237.

Abdelhamid, A.M.; Bassuny , S.M.; Abd El- Aziz ,A.A. and Ibrahim , M.Y.S.A. (2009b). Evaluation of biological treatments for agriculture by-products in ruminants feeding II- Digestion study. J.Agric.Sci. Mansoura Univ., 34: 6239- 6250. 
Abdelhamid , A.M.; Bassuny , S.M.; Abd El- Aziz ,A.A. and Ibrahim , M.Y.S.A. (2009c). Evaluation of biological treatments for agriculture by-products in ruminants feeding IIGrowth of lamb . J.Agric.Sci. Mansoura Univ., 34: 6251- 6259.

Abd El - A ziz , A.A. ; M.E. Lashin ; N. El - Oksh and R. T. Fouad (1993 ). Effect of some mechanical treatment and feed additives on nutritional value of corn stalks 3 . Blood and rumen parameters J. Agric. Sci . Mansoura Univ. $18: 46$.

Abd El-Aziz , G.M. ;Y. E. El-Talty and M.A.Ali (1997 ).Biological treatments of straw in animal nutrition. Egypt $\mathrm{J}$. Nutrition and Feeds , 1:225 - 234 .

Abou- Selim . I.M.and Bendary, M.M.( 2005).Feed stuffs resources in Egypt sources and maximization of its utilization. Proc .2 nd Conf .Anim.Prod. Res.Inst,Sakha ,27-29 September, 57-67.

A.O.A.C.(2000).Association of Official Analytical Chemists Official Methods of Analysis17 ed. Washington D.C.

Austin,R.S.(1967). Distribution of nitrogen and acids of fermentation within urea - treated and untreated corn silage . M.Sc. Thesis Michigan State Univ . East . Lansing, Michigan . USA .

Barnet, A..J.G. (1954) . Silage fermentation Academic Press Int ,New York.

Bendary , M.M ;Mahmoud, A. M. ;Koriet, I. S.and Mahmoud, E.A.(1992 a ).Nutritional studies on using sugar beet tops in animal feeding . 1 Chemical composition and nutritive values of fresh dried sugar beet tops before and after ammonia treatments. Menofiya J. Agric. Res ., $17: 95-107$.

Bendary , M.M ; Mahmoud , A.M ;Koriet, I. S. and Mahmoud, E.A.( 1992 b). Nutritional studies on using sugar beet tops in animal feeding . 2Chemical composition and nutritive values of fresh dried sugar beet tops silages made by different methods .Menofiya J.Agric. Res.,17(1) :109- 121.

Bendary , M.M ;A. M .Mahmoud ; I.S. Koriet ; E.M .Abdelraouf and Awadalla , S.A.(1992c) . Nutritional studies on using sugar beet tops in animal feeding.3-Minerals content of different varieties of sugar beet tops and some minerals balances . Vet . Med .j.Giza ,10:89-98 .

Biomen (2008) . New inoculants for wrapped silage .Indian J . Dairy Sci ., 27 : 251 - 257 Radwan, S ; B.

Chauhan, T.R. and V.,K. Kakkar, ( 1981 ). Feeding value of sugarcan tops silage .Ind. J. Anim. Sci. $51: 221$.

Chauhan, T.R. (1994) .Comparative feeding value of urea with poultry excreta supplemented sugar can tops silage to buffaloes . Ind. J . Dairy Sci . $47: 62$.

Conway , E . J . ( 1962 ) . Microdefusion Analysis and Volumatric Error( 5th Ed) Crosby - L Ockwood and Sons LKtd . Laodon .

Duncan, D.B .(1955).Maltiple range and multiple F-test.Biometrics, 11:1-42 .

Dawson ,K.A.(1992) .Current and future role of yeast cultures in animal production : Areview of research over the six years. In : Supplement to the proceedings of Altech's 8 th Annul symptoms .1:23.

Diekman , M.A. and Green M.L. (1992) .Mycotoxins and reproduction in domestic livestock .J.Anim.Sci.,70; 1615-1627. 
Douman , ab.t.; Waston , W.A. and Homer. (1971).Albumin standards and the measerment of serum albumen with bromo- cresol green . Clinical chemical. Acta, 31: 87-90.

El-Ashry , M.A., Kholif , A.M., Fadel ,El- Alamy ,H.A., El-Sayed ,H.M. and Kholif , S.M.( 2003 ). Effect of bio;ogical treatments on chemical Composition and in vitro and in vivo digestibility's of poor quality roughages . Egyptian J.Nutr. \& Feed, 6: 113-126.

El-Barbary ,M.I. (2008).Aflatoxin B1induced in protein electrophoretic pattern And DNA in Oreochromis niloticus with special emphasis on the protective effect of rosemary and parsley extracts. American Eurasian J.Agric. \& Environ. Sci. , 4(3): 381-390.

El- Dosyki,A.A.;Moshhour,W.,Labab Ebtsam and Abou- shak,Fatma ( 2003) .Scientific leaflet on using useful micro - organisms . EM. Effective micro-organisms ( in Arabic ) Ministry of Agric.and Land Reclamation $A, R, C$, Center Adminstration for AAgric. Extention . scientific leaflet No .755 .

El- Kady , R.I.; I.M.Awadalla ;M.I. Mohamed and M.M.Souky (1999). Utilization of sugar beet tops as fresh and silage by sheep .J.Agric. Sci., Mansoura univ. 24: 6427.

El- Serafy , A.M.(1991) . Efficiency of converting to milk and meat production in models of animal. Poultry and fish nutrition. Sakha, Kafr El- Shikh. 26-28 No . pp. 119 (in Arabic) .

El-Shanaway, A.A.; Mostafa, M.E..and Barakat, A.(2005). Fungal population and mycotoxins in silage in Assiut and Sohage governorates in Egypt , with a special reference to characteristic Aspergilli, toxins. Mycopathologia , 159: 281-289.

Etman , K.I.;E.A.Khafaga ; W.H.Abd El- Malak ; M.K. Hathout and M.F.ElSays (1994).Conserving of green summer forage as silage and its utilization in feeding growing lambs . Egyptian J.Anim. Prod. 31: 175

Fengwu , W.u. ; Zhike He; Qingyao Luo ; Yun'e Zeng ( 1999). determination of oxalicacid of sugar beet tops and spinach .Analytical,TLC.Nutritional and Clinical Methods Section .J. of Food Chem.Vol. 65, Issue 4, P. 543-546.

Gredek,B.S.(1974).Der mikrobiologische. In Unerwunschte Stoffe in futtermitteinund mogliche Ruckstande in Lebensmittein . Dokumentation ober das MFI -Seminar am 17 - 18 Junuar in Wiesbaden , S : $88-\mathrm{m} 106$. der Veterinary hygiene in

Gredek ,B .S . ( 1983 ). Survey of fungal disease in demostic animals . Anim. Res. Develop ., $17: 47-61$.

Heman ,T.and Ttigo-Stockli, D.(2008). Mycotoxins in feed grains and ingredients. Mycotoxins Technical Articles, engormix . Com. , $12 p$.

Hieu,L.T.(1999) .The chemical composition and palatability of ensiled forages as related to moisture content at time of ensilage . Dissertation Abst. Internet (B), 30 , 1966( Nut. Abst. And Rev., 1971, 41: 2472).

Hughes ,M.J. and G. Peralta (1981) .Observation on the effects of sodium Hydroxide aqueous ammonia and urea on ensilage sugar beet tops and pressed can stalk.Trop. Anim. Prod ., $6: 78$

IARC (2002). Aflatoxins .IARCSummary \&Evalution, Volium 82,6p. 
Langston ,C.M.;H.Irwin;C.H.Gordon ;C.Bouma ;H.G.Wisman ;C.G.Melin ; L.A.Moor and J.R.Mccaimant(1958).GrasssilageUSDA,Tech,Bull.1187 .

Mohamed,M.I.(1998). Effect of feeding corn stover treated with ammonia and urea on sheep performance . Ph.D.Thesis ,Fac. OF Agric., Assiut Univ.Egypt

Mohammed, A.. H. k. Ibrahim and H.El- Amary ( 2003 ) . Laincorceration aromatic plants by -products in rumenant diets . rumen fermentation and performance Egyptian J. Nutrition and feeds 7:186 - 197.

Mohsen , M.K.;Bassuni, M.I.;Yacout, M.H. and M.A.M.( 2006) . Nutritional studies on the use of sugar beet tops silage in feeding lactating cow . J.Agric. Rec. tanta Univ. , 32(3):2006.

N R C ( 1990) . National Research Council . Nutrient Requirements of Sheep National and Academy Press, $17^{\text {th }}$ Edition .

Patel , B.R. and Mudgal , V.D. ( 1974 ). Studies on silage making from berseem (Tarifolium alexandrinum) . Indian J . Dairy Sci ., $27: 251$ 257 Radwan, S ; B.

Pollman, D.S.;D.N. Danielson, and E. R . Peo , ( 1980 ) . Effect of microbial feed additives on performance of starter and growing finishing pigs. J. of Animals Sci . $80: 374$.

Qureshi, M.A.;Brake,J.; Hhamilton P.B.Hagler J.R.and Nesheim , S.(1998). Dietary exposure of broiler breeders to aflatoxin results in immune dysfunction in progeny chicks . Polt. Sci. 77(6): 812-819.

Saleh , M.R.M.(1999).Some studies on nephritic mycotoxins in foods and feeds .Ph .D .Sc.Thesis, Fac. of Agric., Mansoura Univ.

Saleh, M. R., Abd- Elmordy, Khalifa, E.I. and El-Emam, G.I.(2007). Oxalic acid effective on milk production and constituents .J. Agric. Sci .Mansoura Univ., 31: 2548 - 2557.

Saleh,M.R.; Abd- Elmordy, and G.I.El-Emam(2008 ).Sugar beet byproducts as animal feed and effects on chemical composition and nutritivevalues on small rummenants .J. Agric. Sci. Mansoura Univ.,32:4235- 4245.

SAS (1996) . SAS / STAT Guide for Personal Computer . SAS inst . Cary , N.C.

Schmeider, B. H. and Flatt, W.P. ( 1975 ) . The Evaluation of Feeds throw the Digestability Experiment. The University of Georgia Press, Athens , $415 \mathrm{p}$.

Swamy,H.V.L.N.(2009).Mycotoxins-part 2 Current thoughts on global mycotoxicoses . World Poultry, 25(7): :18-20.

SPSS (2004). statistical package for the Social Science. Release : 13. SPSS INC ,Chicago, USA.

Tabanah , A. S. A .(1994).Utilization of corn and sunflower plant residues in ruminants nutrition. M. SC . Thesis Fact. of Agric., Cairo Univ. Egypt.

Talha, M. H. A.(1990).Effect of urea treatment on the utilization of corn and sunflower plant residues in rumenants nutrition. M. Sc. Thesis, Fac.of Agric. ,Cairo .Univ. Egypt .

Verma ,D.(2007).New facts about mycotoxin control - intensive research in the field ofmycotoxin deactivation gives new insights.Mycotoxins Technical Articles, engormix .Com ,4 p.

Vertanin,A.I.(1984).Nach Schrifthichen Metteilugmgen Von.(C.F.Hanafy 
Saleh, M. R. M. et al.

1985).

Warner,A.G.T.(1964).Production of volatile fatty acids in the rumen. Methods of mesurment . Nutr. Abstr. And Rev .,34:339

Waldo,D.R. and L.H.Schultz(1996 ) .Lactic and production in the rumen .J. Dairy Sci.39 P1455.

Yacout,M.H.M.(2001).Fermentation characteristics and feeding values of inoculant and ammonia treated corn silage .2nd international Conference on animal production and health in semi - Arid Aeas :205

Zedan ,A.H.(1998) .Silages of corn stalks and sugar can tops in dairy cow .

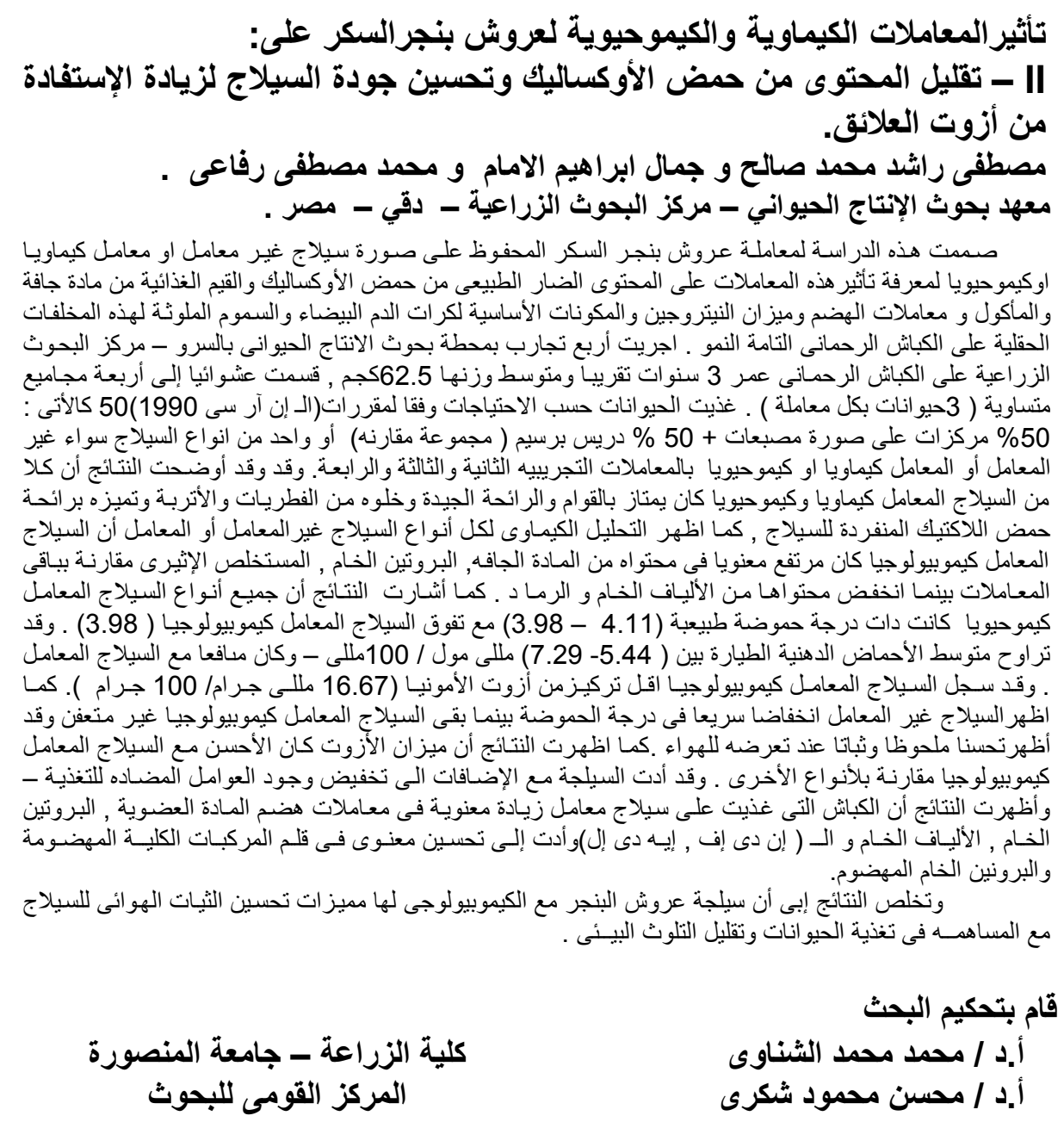


J. Animal and Poultry Prod., Mansoura Univ., Vol.3 (11), November, 2012 